\title{
Property-by-Property Valuation of Publicly Traded Real Estate Firms

\begin{abstract}
Because the assets held by publicly traded real estate companies are infrequently traded, their values must be estimated to determine the relationship between share prices and net asset values for investment purposes. Alternative modeling approaches may be followed to accomplish these valuations, including income-based and transaction-based models. The real estate values of publicly traded firms are estimated in this study using a hedonic pricing model that combines the market's valuation of the fundamental characteristics of the assets with the specific characteristics of each asset being valued. After converting asset values to estimates of net asset values. the net asset values are compared to the market valuations of firms' equity claims. Valuations for two Hotel REITs provide information about market premiums commonly attributable to liquidity and REIT management.
\end{abstract}

\section{Introduction}

The resurgence of REITs, with nearly 100 initial public offerings during the early $1990 \mathrm{~s}$, has renewed investor interest in how securities markets value publicly held real estate and the management of its productive use. ${ }^{1}$ Because REIT management is required to invest $75 \%$ of total assets in real estate, cash. cash items, and government securities to maintain tax-exempt status, REITs offer the opportunity to study relationships between valuations of real estate in the securitized and unsecuritized (property) markets. ${ }^{2}$ Such studies are challenging, in that the securitized claims trade continuously and the unsecuritized claims trade infrequently.

To serve the needs of REIT investors and explore academic interests in real estate market behavior, models must be introduced to estimate the values of the assets held by real estate firms. ${ }^{3}$ Popular asset valuation models have two forms; income-based and transaction-based models. A transaction-based hedonic model, matched with a large database of property transactions, is introduced here to estimate the values of the underlying assets of public-traded real estate firms. The value estimates from the model rely on the asset market's implicit pricing of property characteristics. Following the conversion of asset values to estimates of net asset values, net asset values are compared to the security market's valuations of firms' financial claims. Demonstrations, using data for two hotel REITs. provide information about how the model may be used to estimate market premiums often attributed to liquidity and management.

The remainder of this study is organized into four sections. The next section discusses issues surrounding public and private market valuation of real estate. Section three reviews the models used to value the underlying assets of publicly traded real estate firms.

* School of Hotel Administration. 182 Statler Hall. Cornell University, Ithaca. New York 14853. Date Revised_-June 1996: Accepted-November 1996. 
The hedonic pricing model is introduced and implemented in section four, including demonstrations using data for two hotel REITs. The final section presents the summary and conclusions.

\section{Refinement of the Value Issue}

The study of security market valuations of the underlying assets of firms has two dominant traditions. From one tradition, value questions emerge because of certain latent assets held by firms (Brennen, 1990). Specifically, can firms unlock hidden securities values associated with assets used (now or in the future) in the production of goods and services for their main lines of business (e.g., an office tower owned and occupied by (BM)? The second tradition focuses on value differences of firms relative to the values of assets held for investment, for which, the underlying assets have their own secondary markets. The classic valuation problem from this tradition is the closed-end mutual fund anomaly (Lee, Shleifer and Thaler, 1990). The valuation problem addressed in this study relates to both traditions, but as discussed below, is not perfectly aligned with either.

\section{Latem Assets}

Brennen (1990) argues that, although the real estate owned by firms may contribute to earnings in amounts equal to rental savings, investors cannot easily determine these rental savings. Thus, firms have incentives to sell and leaseback properties to capture any hidden values. Slovin. Sushka and Polonchek (1990), Rutherford (1990) and Alvayay. Rutherford and Smith (1995) confirm that sale and leaseback transactions significantly add to shareholder wealth. Note that real estate owned by firms as investments does not contribute to earnings as the result of rental savings from use in the production of goods and services.

Others argue that shareholders benefit from real estate asset or unit divestitures and other forms of firm restructurings involving real estate because security market investors sometimes undervalue real estate. given the infrequency of asset trades (Brueggeman, Fisher and Porter, 1990). ${ }^{4}$ Event studies also support this type of the latent asset claim by showing that real estate divestitures (Owers and Rogers, 1986; Glascock, Davidson and Sirmans, 1989, 1991; Myer. He and Webb. 1992: McIntosh, Ott and Liang. 1994), and spin-offs (Hite, Owers and Rogers, 1984: Rutherford and Nourse, 1988; and Ball. Rutherford and Shaw, 1993) produce favorable shareholder wealth effects. The assets of real estate investment firms, such as REITs, are likely to be less undervalued than latent assets because specific information normally is provided in offering prospectuses, and other reports (e.g. annual, 10-Q) about property-level operations and income generation. ${ }^{5}$ Nevertheless, several studies examining the wealth effects from REIT announcements of portfolio changes provide evidence of abnormal return behavior. McIntosh. Ott and Liang (1995) report no significant wealth effects from REIT property acquisitions, but significant positive returns from property dispositions. Also. Elayan and Maris (1991) find significant wealth effects from announcements of REIT liquidations. In pursuit of direct evidence of REIT mispricing, Gau and Wang (1991) study REIT announcements of current asset values using appraised values estimated by firms" management or by independent appraisers and find significant, positive shareholder wealth effects. Damodaran 
and Liu (1993) fail to detect a market response to public announcements of appraised values, but their results strongly support the hypothesis that insiders trade on favorable and unfavorable news about current asset values from appraisals. Although REITs and other real estate firms do not hold latent assets, mounting empirical evidence suggests that their assets retain value not demonstrated in share prices. ${ }^{6}$

\section{Closed-End Funds}

Real estate investment trusts resemble closed-end investment companies. Unlike closedend funds. REITs are restricted in their investment activities and their assets are not continuously traded. Closed-end funds trade at prices that differ from their net asset values despite the fact that these funds consist of shares of companies for which the prices are directly observable. Country funds trade at premiums and discounts, while United States closed-end funds trade at discounts. ${ }^{7}$

Many possible explanations for closed-end fund premiums and discounts have been put forward including reasons related to option value (Ingersoll, 1976), tax liabilities, operating costs, broker effort, liquidity, and most recently, the unpredictable behavior of small investors (Lee, Shleifer and Thaler, 1991). Also, among the more widely accepted explanations is management performance.

\section{Private and Public Values of REITs}

The real estate professional literature contains numerous claims of REIT mispricing. Edmunds (1982) contends that investors consider earnings and not cash fow in making incorrect valuations of REITs. Downs (1994) argues that valuations in the property market (i.e., private values) and valuations in the securities market (i.e., public values) naturally diverge. He claims that property markets look backward while securities markets look forward; securities market participants do not think about or place values of properties unless a REIT represents a securitized claim against only one property; REIT prices reflect movements in the stock market and not the real estate market; interest-rate movements affect property and security markets in different ways; and other factors act uniquely on one market or the other (e.g., tax law changes). He makes the strongest case for REIT discounts or premiums from net asset values based on the management of the operating company. Beneficial management raises the future values of existing assets, it buys and sells assets at the correct times in the real estate cycle, and it develops new properties when profitable. Poor management creates discounts from net asset values because of suboptimal decisionmaking.

Behrens (1994) argues, without empirical support, that REITs trade at premiums to net asset values because of the combination of a liquidity premium and a management service premium. Many REITs are seen as targets for leveraged buyouts because of increasingly advantageous private value-to-public value relationships (Scherrer, 1995). Finally, Green Street Advisors (1996) lists the following reasons for REIT premiums over net asset values:

- REITs make real estate a liquid investment:

- REITs are capable of adding value;

- REITs are efficient operators;

- REITs offer diversification. 
The relationship between the private values and public values of real estate is important to investors seeking undervalued firms, looking for firm restructuring opportunities, and to both the professional and academic real estate interests in measuring the contributions of liquidity and management to value. This relationship is different from the private value and public value relationship involving latent assets because the assets of real estate investment firms are held for investment and are not latent-held for income generation from production of non-real estate goods and services. This relationship also differs from the relationship underlying the closed-end fund anomaly because the assets of real estate investment firms, although easily identified, are not continuously traded.

A model(s) may be introduced for valuing the underlying assets of publicly traded real estate companies in an effort to quantify the private value. The next section of this study reviews the models proposed to accomplish this task, and the evidence of premiums and discounts from net asset values of real estate investment firms generated with these models.

\section{Alternative Models}

The valuation models reviewed in this section are income-based models. Some of these models treat the real estate firm as a going concern operating with a latent asset base of properties, while other models treat the real estate firm as a closed-end fund that owns a collection of assets, each of which may be valued separately.

\section{Hall (1994)}

Hall (1994) proposes a model for analyzing the contribution of REIT management to REIT prices based on a regression equation that has REIT share price on the left side and selected financial statement variables on the right side. The model is designed for research purposes, not to produce REIT valuations. Hall's central hypothesis about the contribution of REITs business management to share price is tested by including the ratio of general and administrative expenses to total assets in the model as "indicative of the business operations intensity in each REIT" (p. 18). He finds no statistically significant relationship between REIT prices and the measure of management intensity, but concludes that "It does not, however, address the quality of management" (p. 18). ${ }^{8}$

\section{Capozza and Lee (1995) and Capozza and Sequin (1996)}

In work by Capozza and Lee (1995) and Capozza and Sequin (1996), an income-based model is developed for valuing REIT assets. The model outputs are used to test hypotheses about management and firm value. Capozza and Lee (1995) compute REIT net asset values (NAVs) as follows:

$$
N A V=\frac{\text { Market Vulue of the Properties }+ \text { Other Assets-Total Liabilities }}{\text { Number of Shares Outstanding }} .
$$

The premium (i.e.. excess public value over the private value) is defined as:

$$
\text { Premiam }=\frac{(\text { Share Price }-N A V)}{\text { NAV }} .
$$


The average annual premiums for the sample of seventy-five REITs range from a $35.9 \%$ discount in 1990 to a $13.4 \%$ premium in $1986 .^{\circ}$

All inputs to the NAV model come from publicly available sources except the market value of the properties. To estimate property values, Capozza and Lee (1995) design a weighted average capitalization approach. First, they derive property-level capitalization rates. Second, these capitalization rates are converted to a portfolio-level capitalization rate using a weighting procedure that recognizes the composition of the REIT's property asset base. Finally, the portfolio-level capitalization rate is applied to firm-level property net operating income to estimate the market value of the properties.

The reliability of this valuation procedure and thus the reliability of the premium and discount estimates, hinges on confidence in the accuracy of property-level capitalization rate estimates. The infrequency of trades requires that property-level capitalization rates be obtained from comparable sales data or by one of the many other methods found in the appraisal literature. Unfortunately, Capozza and Le (1995) do not identify the model or otherwise inform about the property-level capitalization rate estimation procedure. Further, no information is given about the property value estimates.

In the second study. Capozza and Sequin (1996) extend Hall's (1994) regression analysis by desegregating general and administrative (G\&A) expenses into systematic and unsystematic components. The systematic component measures the firm's "focus" (p. 3), and "its strategy or structure" (p. 5). The systematic G\&A expenses enter a regression as an explanatory variable with share price on the left side.

The regression has the following form:

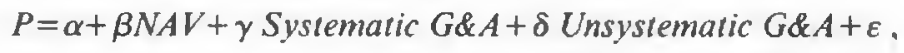

where:

$P=$ share price.

Net asset value, measured using the method in Capozza and Lee (1995), is positive and highly significant in this regression and systematic G\&A expenses are negative and significant.

\section{Green Street Advisors (1996)}

Similar in structure to Capozza and Lee (1995), the Green Street Advisors (1996) approach to the valuation of REIT properties is based upon capitalizing net operating income from the property portfolio. They develop 'economic cap rates' that 'equate to the unleveraged yield on a property after deducting a normalized reserve for reoccurring. capitalized leasing and maintenance costs ("cap-ex") from real estate' (p. 5). No details are provided about the derivation of property capitalization rates except that several factors contribute to the choice of rates including property type, location, quality and age, and expected demand growth for the property type.

\section{Alex. Brown \& Sons (1993)}

The intricate valuation model developed by Alex. Brown \& Sons (1993) views the REIT as a firm generating funds from operations (FFO). ${ }^{10}$ The model discounts FFO using a 
weighted average internal rate of return for the REIT industry. The weighting procedure recognizes that $\mathrm{REITs}$ are hybrid securities possessing characteristics unique to real estate (e.g., 20\%), stocks (e.g., 30\%) and bonds (50\%). "Thus, the denominator of the model requires internal rates of return for real estate. stocks and bonds, and the weights for each.

The calculation of the income for the numerator of the model begins with reported FFO. Adjustments to FFO are made for a variety of factors endemic to the REIT. including portfolio management, acquisition management, and financial structure and management net of management expenses. These adjustments capture management's incremental contributions to future FFO growth. Finally, the sum of existing FFO and future FFO adjustments is scaled by a factor, I, that incorporates seven investor considerations, including business focus and stock ownership by management. Combining this numerator with the weighted average internal rate of return produces a value estimate for the REIT.

The Alex. Brown \& Sons model clearly differs in its structure from the other models reviewed in this section in that it values the firm without attempting to directly value the firm s assets. In other words, a latent asset approach is followed rather than a closed-end fund approach. The problem of determining property-specific capitalization rates thus is avoided. This is not to say that creating the real estate internal rate of return for real estate as part of the weighting process is any simpler than finding property-specific capitalization rates.

The report that describes the Alex. Brown \& Sons model provides a 'black box'. Most of the inputs needed to produce the numerator and denominator of the model appear to require analyst judgment. Perhaps Alex. Brown \& Sons has highly developed, objective models supporting each input. The report provides no details about how the internal rates of returns, the weights, and the FFO adjusters are specified.

\section{Valuing Commercial Properties with Hedonic Pricing Models}

Hedonic pricing models have been applied to the valuation of residential properties for many decades. A culmination of these applications came recently with the introduction by Fannie Mae and Freddie Mac of nationwide residential loan underwriting systems that include 'collateral assessment' components (i.e., residential appraisal) based upon hedonic pricing technology. Because of the infrequency of trades in commercial property markets, the development of large transaction databases has been slow, thus limiting applications of hedonic pricing to commercial properties.

Commercial property hedonic models are more abundant when the objective is to model rents rather than to model asset values. ${ }^{12}$ Nevertheless, asset price equations have been estimated from as early as 1980. Hoag (1980) and, recently, Crossman, Dannis and Thibodeau (1996) develop equations that mix highly collinear property income variables with property characteristic, location and local market variables. Miles, Hartzell, Guilkey, and Sears (1991) conclude that transaction-based indexes for local markets will develop slowly due to the small number of transactions that occur in each market relative to the needs of these models, and due to the reluctance of market participants to share transaction information.

Others, including Webb, Miles and Guilkey (1992), Fisher, Geltner and Webb (1994), and Geltner (1996) produce regression-based asset pricing models to answer broad 
research questions about real estate markets. They all advocate further development of hedonic models to enhance investment performance measurement.

\section{Hedonic Pricing of REITs}

A hedonic model may be successfully introduced to estimate the values of REIT properties; and thus NAV, premiums and discounts, if the model possesses a high degree of conceptual and statistical validity. The model should have a structure that conforms to the time-tested structure of residential hedonic models. The parameters should be estimated with a large database of property transactions in each local market that extend over a complete real estate cycle. Hedonic pricing represents a different and probably more objective approach to estimating property values for computing NAVs than the popular income-based approaches.

In a series of papers, Corgel and deRoos $(1992,1994 a, b)$ introduce a hedonic model of lodging-property asset prices and estimate the parameter vector with a large database of lodging-property transactions.

The functional form of the generalized hedonic equation is:

$$
C E P_{i}=f\left(P_{i}, L_{i}, E_{i}, T_{i} ; \beta, e\right) \text {, }
$$

where:

$C E P_{i}=$ cash equivalent sale price of the $i$ th property:

$P_{i}=$ vector of physical characteristics of the $i$ th property;

$L_{i}=$ vector of locational characteristics of the ith property:

$E_{i}=$ vector of economic characteristics of the local area in which the $i$ th property is located:

$T_{i}=$ time of sale of the $i$ th property;

$\beta, e=$ estimated parameters of the model and the error term.

Exhibit I presents a list and brief description of the variables used to measure the characteristics defined above.

The property transaction data for this study comes from a large database of hotel and motel transactions. The data are national in scope and include a large number of the lodging-property transactions that occurred during the period beginning in the first quarter 1985 and ending in the last quarter 1994.

The primary source of transaction information is the Hospitality Market Data Exchange maintained by Hospitality Valuation Services (HVS), an appraisal firm. From this source comes the sale price, number of rooms, date of sale, and general location information. Certain information about the characteristics of the properties, such as age. amenities and the conditions of the sales (e.g., financing terms) were obtained during visits to the appraisal firm's office. Other data come from the following sources:

- Hotel \& Travel Index; the AH\&MA Hotel and Motel Redbook; and Mobil Travel Guides:

- Members of the Hotel and Motel Brokers Association;

- Telephone interviews with hotel and motel managers;

- Bureau of Labor Statistics and U.S. Bureau of Census; and

- Sales and Marketing Management magazine. 


\section{Exhibit 1 \\ Variable List and Descriptions}

\begin{tabular}{ll}
\hline Variables & \multicolumn{1}{c}{ Description } \\
\hline$P$ & $=$ Selling price adjusted for extraordinary financing and ground leases. \\
ROOM & $=$ Number of rooms at time of sale. \\
AGE & $=$ Age in years at time of sale. \\
CHAN & $=$ Affiliation with major lodging chain $(1,0)$. \\
SUIT & $=$ All suite lodging properties $(1,0)$. \\
COURT & $=$ Log of the number of tennis courts at a property. \\
$C O U R S E$ & $=$ Property with a golf course $(1.0)$. \\
$P O O L$ & $=$ Log of the number of pools at a property. \\
REST & $=$ Properties with food and beverage operations $(1,0)$. \\
$D A I R$ & $=$ Time in minutes between a property and the nearest airport. \\
$D C O M$ & $=$ Time in minutes between a property and the nearest commercial center. \\
$E M P$ & $=$ Number of employed persons in the county during the month of sale. \\
$E B I L A G$ & $=$ Effective buying income per capita in the county during the year prior to sale. \\
$D$ & $=$ Dummy for period of sale.
\end{tabular}

The entire database includes more than 1,600 transactions. Although the sample is not randomly chosen. efforts were made to avoid concentrations of property sales by quarter, geographic region, chain affiliation. and other property characteristics.

Running equation 4 repeatedly with the database to predict the value for each property owned by a REIT, every time multiplying the coefficient vector by the vector of propertyspecific characteristics, generates an estimate of the market value of the properties needed to estimate NAV in equation I. Following Capozza and Lee (1995), the premium (discount) of a REIT is estimated from equation 2.

\section{Model Tests}

Two hotel REITs, Felcor Suite Hotels, Inc. and Jameson Inns. Inc., are selected to test the method described in the previous section.

\section{NAV and Premiums for Felcor}

Felcor Suite Hotels, Inc. is a Delaware corporation formed in May 1994. The initial public offering of the REIT's stock occurred in July 1994. at which time the company held a $70.6 \%$ interest in a partnership that owned six properties (1479 suite rooms) located in Florida, Oklahoma, Tennessee, and Texas. During November 1994, the Felcor partnership acquired a property in New Orleans. All properties carry the Embassy Suites brand.

The sponsors and managers of the Felcor REIT are former executives of Embassy Suites. They set Felcor on an aggressive growth path. Since the end of 1994, Felcor acquired thirteen Embassy Suite properties and successfully completed two secondary stock offerings.

The NAVs of Felcor are estimated for the third and fourth quarters of 1994 using two hedonic pricing approaches. First, a semi-log regression is run with fundamental variables and quarterly time dummies shown in Exhibit 1 using a database of 1661 
lodging-properties sold throughout the United States from the first quarter 1985 through the fourth quarter 1994. Sale prices are adjusted for non-market financing. All but one of the fundamental variables (COURSE) are significant at the .10 level. Most of the time dummies also are significant. The regression has an $F$-value of 68.6 and an adjusted $R^{2}$ of $67.9 \%$. The model yields value predictions for each Felcor property owned during the third quarter 1994 and during the fourth quarter 1994. The aggregate property value is introduced in equation (1) and then equation (2) generates the estimates of NAV and premiums (discounts).

Second, the identical procedures to those described above are followed except the model is run with suite-property sales. The database includes only ninety-seven suiteproperty transactions and during some quarters, no suite-property sales occurred. Thus an annual model is run instead of the quarterly model. Fewer fundamental variables and time dummies have significant coefficients in the suite-property regression than in the allproperty regression. Insignificant variables include $A G E$. CHAN, COURTS, and COURSE. notwithstanding, the $F$-value is 12.72 and the adjusted $R^{2}$ is $75.1 \%$.

Exhibit 2 compares the computed NAVs and share prices of Felcor in the third and fourth quarters 1994 from the all-property regression and in 1994 from the suite-property regression. Fourth-quarter liabilities, other asset totals, and share prices are combined with the results from the 1994 suite-property model to form the NAV of \$17.53. Information on the other assets, liability and minority interests was obtained directly from Felcor financial statements. ${ }^{13}$

Premiums of $12 \%$ to $14 \%$, and $39 \%$ for the fourth quarter 1994 , are found. Felcor purchased one property during the fourth quarter 1994 for $\$ 25.7$ million. The purchase reduced other assets and increased liabilities by approximately the amount of the purchase. The model valued the additional property at considerably below the purchase price ( $£ 10$ million). Also, the share price declined from the third to fourth quarter. The net result of these changes was that Felcor sold (probably temporarily) at a substantial premium to NAV during the fourth quarter 1994.

\section{Exhibit 2}

Net Asset Values and Market Pricing of Felcor Suite Hotels, Inc. during 1994

\begin{tabular}{|c|c|c|c|c|c|c|c|}
\hline Model & $\begin{array}{l}\text { Hedonic } \\
\text { Model Ests. } \\
\text { of Prop. } \\
\text { Values }^{\text {a }}\end{array}$ & $\begin{array}{c}\text { Other } \\
\text { Assets }^{b}\end{array}$ & $\begin{array}{l}\text { Liabilities } \\
\text { and Minority } \\
\text { Interests }^{\mathrm{b}}\end{array}$ & Shares & NAV $^{\mathrm{c}}$ & $\begin{array}{l}\text { Share } \\
\text { Price }\end{array}$ & $\begin{array}{c}\text { Percent } \\
\text { Premium } \\
(+)^{\mathbf{e}}\end{array}$ \\
\hline \multicolumn{8}{|c|}{ All Properties } \\
\hline \multicolumn{8}{|c|}{ Third Quarter } \\
\hline 1994 & $\$ 101,798,872$ & $\$ 17,586,000$ & $\$ 26,100,000$ & $4,719,000$ & $\$ 19.77$ & $\$ 22.58$ & +14.2 \\
\hline \multicolumn{8}{|c|}{ Fourth Quarter } \\
\hline 1994 & $\$ 104,586,202$ & $\$ 2,246,000$ & $\$ 39,050,000$ & & $\$ 14.36$ & $\$ 20.04$ & +39.5 \\
\hline \multicolumn{8}{|c|}{ Suite-Properties } \\
\hline 1994 & $\$ 119,554,659$ & $\$ 2,246,000$ & $\$ 39,050,000$ & & $\$ 17.53$ & $\$ 20.04$ & +12 \\
\hline
\end{tabular}

Afrom equation (4); bfrom 100 and 10k reports; " ${ }^{\circ}$ from equation (1); ‘quarterly share prices are midpoints of the range of share prices during the quarter; " 


\section{NAV and Premiums for Jameson}

Jameson Inns, Inc. was reincorporated in Georgia during 1993. On January 1, 1994 Jameson began operating as a REIT with fifteen budget, limited-service properties (707 rooms) located throughout the southwestern United States. The initial public offering perspectus revealed that Jameson would open two additional properties during February 1994.

Management is experienced in lodging-property development and construction. This REIT is one of a few that pursues a develop-and-hold strategy. During 1995 Jameson completed construction of eighteen additional properties.

The NAVs of Jameson are estimated for the four quarters of 1994 using similar hedonic pricing approaches to those used for Felcor. First, the all-property model $(N=1661)$ is introduced to predict the values of properties held by Jameson. Second, a limited-service property model is estimated. and applied in the same way as the suite-property model is applied in the case of Felcor. Despite the fact that the database contains 538 limitedservice property transactions, few limited-service transactions during 1994 appear in the database. Thus, the model is estimated with annual dummies. This equation has an $F$ value of 29.2 and an adjusted $R^{2}$ of $57.7 \%$. Most of the dummy variable coefficients are significant at the .05 level, but only about one half of the fundamental variable coefficients are significant at that level. Insignificant variables include $A G E, C H A N$, COURT, COURSE. DAIR, and DCOM.

The premiums derived from the hedonic model valuation of Jameson's properties, shown in Exhibit 3, varied considerably throughout the four quarters of 1994. Information on other assets and liabilities comes from Jameson's financial statements. The highest premium was over $75 \%$ in the third quarter and the lowest was $18.4 \%$. Because of

\section{Exhibit 3}

Net Asset Values and Market Pricing of Jameson Inns, Inc. during 1994

\begin{tabular}{|c|c|c|c|c|c|c|c|c|}
\hline Model & $\begin{array}{c}\text { Hedonic } \\
\text { Model Ests. } \\
\text { of Prop. } \\
\text { Values }^{\text {a }}\end{array}$ & & $\begin{array}{l}\text { Other } \\
\text { Assets }^{b}\end{array}$ & Liabilities $^{b}$ & Shares & NAV & $\begin{array}{l}\text { Share } \\
\text { Price }^{d}\end{array}$ & $\begin{array}{c}\text { Percent } \\
\text { Premium } \\
\qquad(+)^{e}\end{array}$ \\
\hline \multicolumn{9}{|c|}{$\begin{array}{l}\text { All Properties } \\
\text { First Quarter }\end{array}$} \\
\hline $\begin{array}{c}1994 \\
\text { Second }\end{array}$ & $\$ 22,473,074$ & $\$$ & 674,000 & $\$ 2,632,000$ & $3,852,353$ & $\$ 5.33$ & $\$ 8.00$ & +50 \\
\hline $\begin{array}{c}1994 \\
\text { Third Q }\end{array}$ & $\$ 25,767,035$ & & $1,118,000$ & $\$ 4,368,000$ & & $\$ 5.85$ & $\$ 7.87$ & +34.5 \\
\hline $\begin{array}{c}1994 \\
\text { Fourth Q }\end{array}$ & $\$ 25,378,874$ & $\$$ & 596,000 & $\$ 7,352,000$ & & $\$ 4,83$ & $\$ 8.50$ & +75.9 \\
\hline 1994 & $\$ 23,444,144$ & $\$$ & 407,000 & $\$ 262,000$ & & $\$ 6.12$ & $\$ 7.43$ & +21.4 \\
\hline \multicolumn{9}{|c|}{$\begin{array}{l}\text { Limited-Service Property } \\
\text { Full Year }\end{array}$} \\
\hline 1994 & $\$ 23,198,741$ & $\$$ & 407,000 & $\$ 262,000$ & & $\$ 6.06$ & $\$ 7.43$ & +18.4 \\
\hline
\end{tabular}

afrom equation (4): 'brom 100 and 10k reports; ' from equation (1); dquarterly share prices are midpoints of the range of share prices that quarter; efrom equation (2) 
Jameson's development strategy and lack of seasoning as a publicly traded company, the variability of quarterly premiums to NAV is not surprising.

\section{Conclusion}

The share prices of publicly traded real estate firms should be well aligned with the firm's NAVs, the largest component of which is the value of the underlying property portfolio. In a competitive market, shares trade within a range of a few percent above NAVs, as the market accounts for the contribution of management and perhaps illiquidity. The market for shares is publicly traded real estate companies, however, is not perfectly competitive. This market suffers from agency problems, the closed-end fund problem, and perhaps other problems identified in the professional literature. Thus, the shares of real estate firms may trade at substantial premiums or discounts.

The analysis of two hotel REITs in this study finds premiums of $12 \%-75 \%$ during 1994. Others, including Capozza and Lee (1995) and Green Street Advisors, Inc. (1996) report discounts of $39.9 \%$ to premiums of $13.4 \%$ and discounts of $9 \%$ to premiums of $29.3 \%$, respectively. ${ }^{14}$ Notwithstanding, the anchor to which share prices are tied is the value of the underlying property portfolio. This means that modeling property values is pivotal to determining the extent of period-to-period overpricing and underpricing.

Hendershott (1966, p. 57) begins a recent article with the following statement "Valuation of income-producing properties in market economics is generally based on the comparable sales method, with the basis of comparison usually being the last year's or expected next years' cash flow." Hedonic pricing is a direct and objective application of sales comparison methodology. Because publicly traded real estate companies do not report income at the property level, hedonic models may represent the best way of obtaining property value estimates, despite the shortcomings of applying these models to income-producing properties as noted by Miles et al. (1991).

\section{Notes}

'Realy' Stock Review' provides complete listings of REIT initial public offerings and follow-on offerings.

2Qualifying real estate includes land and improvements, mortgages, shares in other REITs, and interests in real estate partnerships. For a summary of the laws governing REIT organization, see National Association of Real Estate Investment Trusts (1995a,b).

${ }^{3}$ The valuation issue extends to al firms with high concentrations of real estate, not only REITs. Some examples of these firms are Host Marriott and foreign property trusts.

${ }^{4}$ For a recent review of the literature on corporate restructuring involving real estate, see Rodriguez and Sirmans (1996).

${ }^{5}$ Considerable information also becomes available when firms acquire and dispose of property.

"These findings are for short periods only. In the long run, the returns from REIT investment may be estimated from accounting returns (Goebel and Ma, 1993).

'See Radcliffe (1994), Ch. 20, "Selection of Active Managers" for a detailed discussion.

${ }^{8}$ The paper does not provide any statistics from this regression. An additional regression is run with the ratio of general and administrative expenses to total assets on the left side, but this regression yields no evidence of private and public value disparities.

"Premiums are computed and reported on a value-weighted basis.

"See National Association of Real Estate Investment Trusts (1995a) for the formal definition of FFO. 


\footnotetext{
"These weightings come from an example in the Alex. Brown \& Sons (1993, p. 5) report. The heavy weighting given to bonds is because of the high current yields of REITs.

'For a review of apartment rent hedonic models see Benjamin and Sirmans (1994). For an example of an office rent hedonic model application. see Wheaton and Torto (1994).

${ }^{13}$ Felcor REIT owns approximately $70 \%$ of the partnership that owns the properties. Thus, the NAVs are adjusted for minority interests as indicated in Felcor's financial statements.

${ }^{14}$ The Green Street Advisors, Inc. results are reported in Goodman and Madden (1996).
}

\section{References}

Alex. Brown \& Sons, Inside the REIT Return, Research-Real Estate Securities. May 1993.

Alvayay, J. R.. R. C. Rutherford and W. S. Smith, Tax Rules and the Sale and Leaseback of Corporate Real Estate, Real Estate Economics, 1995. 23:2. 207-38.

Ball, J. N., R. Rutherford and R. Shaw. The Wealth Effects of Real Estate Spin-Offs, Journal of Real Estate Research, 1993, 8:4, 597-606.

Beals, P., Hotel Assessment Management: A Valued Function with a Problematic Future, Real Estate Review, 1996, 26:1, 42-47.

Behrens, R. J., Valuation of Equity Real Estate Investment Trusts, Appraisal Journal, 1994, 62:1. $150-52$.

Benjamin, J. D. and G. S. Sirmans, Apartment Rent: Rent Control and Other Determinants, Journal of Property Research. 1994, 11:1, 27-50.

Brennan. M. J., Latent Assets. Journal of Finance, 1990, 45:3, 709-30.

Brueggeman, W. B., J. D. Fisher and D. M. Porter, 1990, Rethinking Corporate Real Estate, Journal of Applied Corporate Finance, 3:1, 39-50.

Capozza, D. R. and P. J. Seguin, Corporate Structure, Managerial Expenses, and Firm Value. working paper, University of Michigan, January 1996.

Capozza, D. R. and S. Lee. Property Type, Size, and REIT Value, Journal of Real Estate Research. 1995, 10:4. 363-79.

Corgel, J. B. W. McIntosh and S. H. Ott. Real Estate Investment Trusts: A Review of the Financial Economics Literature, Journal of Real Estate Literature, 1995, 3:1, 13-43.

Corgel. J. B. and J. A. de Roos, Pure Price Changes of Lodging Properties. Cornell Hotel and Restaurant Administration Quarterly, 1992, 33:2, $70-77$.

- The ADR Rule-of-Thumb as Predictor of Lodging Property Values, Imternational Journal of Hospitality Management, 1994a, 12:4, 353-65.

- Buying High and Selling Low in the Lodging Property Market, Cornell Hotel and Restcuran Administration Quarterly, 1994b, 35:6, 33-38.

Crossman, S. T.. C. G. Dannis and T. G. Thibodeau, Regression Analysis: A Cost-Effective Approach for the Valuation of Commercial Portfolios, Real Estate Finance. 1996, 13:4. 20-28.

Damodaran, A. and C. H. Liu, Insider Trading as a Signal of Private Information, Review of Financial Studies, 1993, 6:1, 79-119.

Downs, A., Public, Private Market Valuations Do Diverge, National Real Estate Investor, 1994, $36: 13,20-24,84$.

Edmunds, J. C., Why REIT Stocks are Undervalued, Real Estare Review, 1982, 12:3, 96-99.

Elayan, F. and B. A. Maris. Stock Market Responses to Voluntary Liquidations and Reorganizations of Real Estate Companies, Journal of the American Real Estate and Urban Economics Association, 1991, 19:1, 92-101

Ennis, J. L., Real Estate Commingled Fund Valuation: Disconnected from the Public Markets, Real Estate Finance. 1996, 12:3, 36-41. 
Fisher, J. D., D. M. Geltner and R. B. Webb, Value Indices of Commercial Real Estate: A Comparison of Index Construction Methods, Journal of Real Estate Finance and Economics, $1994,9: 2,137-64$.

Gau, G. W. and K. Wang, Current Value Reporting and the Stock Market Valuation of Real Estate Companies, working paper, Department of Finance, University of Texas, December 1991.

Geltner, D., The Repeated-Measures Regression-Based Index: A Better Way to Construct Appraisal-Based Indexes of Commercial Property Value, Real Estate Finance, 1996, 13:4, 29-35.

Glascock, J. L., W. N. Davidson and C. F. Sirmans, An Analysis of the Acquisition and Disposition of Real Estate Assets, Journal of Real Estate Research, 1989, 4:3, 131-40.

Goebel, P. R. and C. K. Ma, Stock Returns and Business Performance of REITs, working paper. College of Business, Texas Tech University, 1993.

Goodman, S. E. and P. H. Madden, Seven REIT Acquisition Targets, Real Estate Review, 1996. 26:1, 11-21.

Green Street Advisors, Inc., REIT Pricing-Poised for a Rebound?: An Update of Our Pricing Mode, Research, January 2, 1996.

Hall, J.. The Intangible Business Component of Commercial Real Estate Investment, Real Estate Issues. 1994. 19:1, 13-22.

Henderschott, P. H., Valuing Properties When Comparable Sales Do Not Exist and the Market is in Disequilibrium, Journal of Property Research, 1996, 13:1, 57-66.

Hite, G. L., J. E. Owens and R. C. Rogers, The Separation of Real Estate Operations by Spin Off. AREUEA Journal, 1984, 12:3, 318-32.

Hoag. J., Toward Indices of Real Estate Value and Return, Journal of Finance, 1980, 35:2, 569-80.

Howe. J. S. and J. D. Shilling, REIT Advisor Performance, AREUEA Journal, 1990, 18:4, 479_ 500.

Ingersoll, J., A Theoretical and Empirical lnvestigation of Dual Purpose Funds: An Application of Contingent Claims Analysis, Journal of Financial Economics, 1976, 3:1, 83-124.

Lee. C., A. Shleifer and R. Thaler, Anomalies: Closed-End Mutual Funds, Journal of Economic Perspecrives, 1990, 4:4, 153-64. 75-109.

Litı, J., Hotel REITs-Under Seige, United States Real Estate Research, Equity Real Estate Securities, Salomon Brothers, November 8, 1994.

McIntosh, W., S. H. Ott and Y. Liang, The Wealth Effects of Real Estate Transactions: The Case of REITs, Journal of Real Estate Finance and Economics, 1995, 10:3, 299-307.

Miles, M., D. Hartzell, D. Guilkey, and D. Sears, A Transactions-Based Real Estate Index: Is It Possible? Journal of Property Research, 1991, 8:3, 203-17.

Morgan, S., Comparative Valuations of REITs: October 1995, U.S. Invesiment Research Real Estate Monthly, October 3, 1995.

Myer, F. C., L. He and J. Webb. Sell-Offs of U.S. Real Estate: The Effect of Domestic Versus Foreign Buyers of Shareholder Wealth, Journal of the American Real Estate and Urhan Economics Association, 1992, 20:3, 487-500.

National Association of Real Estate Investment Trusts, Inside REITs, Washington, D.C.: NAREIT, 1995a.

- Laws Affecting REITs, Washington, D.C.: NAREIT, 1995b.

Owers, J. E. and R. C. Rogers, The Divestiture of Real Estate Assets by Sell-Offs, Real Estate Issues, 11:1, 29-35.

Palmon, D. and L. J. Seidler, Current Value Reporting of Real Estate Companies and a Possible Example of Market Inefficiency, Accounting Review', 1978, 53:3,776-90.

Radcliffe, R. C., Investment, New York: HarperCollins. 1994. 
Rodriguez, M. and C. F. Sirmans. Managing Corporate Real Estate: Evidence from the Capital Markets, Journal of Real Estate Literature, 1996, 4:1, 13-33.

Rutherford, R. C., Empirical Evidence on Shareholder Value and The Sale-Leaseback of Corporate Real Estate, AREUEA Journal. 1990, 18:4, 522-29.

- and H. O. Nourse. The Impact of Corporate Real Estate Unit Formation on the Parent Firm's Value, Journal of Real Estate Research. 1988, 3:3, 73-84.

Scherrer, P. S., REITs Are Attractive LBO Targets, Real Estate Review, 1995, 25:4, 38 42.

Shilling, J. D., C. F. Sirmans and J. W. Wansley, Do REITs Trade at a Discount? Some Indirect Evidence. Working Paper No. 63, Real Estate Center, Louisiana State University, 1986.

Slovin, M. B., M. E. Sushka and J. A. Polonchek, Corporate Sale-and-Leaseback and Shareholder Wealth, Journal of Finance, 1990, 45:1, 289-99.

Webb. R. B., M. Miles and D. Guilkey, Transaction-Driven Commercial Real Estate Returns: The Panacea to Asset Allocation Models, Journal of the American Real Estate and Urban Economics Association, 1992, 20:1, 325-57.

Wheaton, W. C. and R. G. Torto. Office Rent Indices and Their Behavior over Time. Journal of Urhan Economics, 1994, 35:1. 127-39.

Financial support for this research is from the Cornell University School of Hotel Administration. Invaluable research assistance was provided by Ifigenia Palimeri. 